\title{
Towards Global Uniformity and Sustainable Compensation Valuation for Compulsory Land Acquisition
}

\author{
Olusegun Olaopin Olanrele ${ }^{1}$, Anuar Alias ${ }^{2 \star}$, Rosli Said ${ }^{2}$, and Nurudeen Akinsola \\ Bello $^{3}$ \\ ${ }^{1}$ Department of Estate Management and Valuation, School of Environmental Studies, \\ Moshood Abiola Polytechnic, Abeokuta, Ogun State, Nigeria \\ ${ }^{2}$ Centre for Sustainable Urban Planning and Real Estate (SUPRE), Faculty of Built \\ Environment, University of Malaya, 50603 Kuala Lumpur, Malaysia \\ ${ }^{3}$ Department of Estate Management, Faculty of Environmental Sciences, University of Ilorin, \\ Ilorin, Nigeria \\ *anuar_a@um.edu.my
}

\begin{abstract}
Compulsory land purchase is a tool for the control of land uses as well as land acquisition for developmental projects by the public authorities (governments). The right of government to compulsorily acquire land for its physical project is domicile in relevant laws of different countries and the laws usually provide for compensation often in money terms to the land/property owners whose land were confiscated. This study focuses on the examination of the compensation process of some countries across the continent in a search for a global standard for uniformity. The paper adopted a content analysis of the provisions of compulsory land purchase laws of selected countries and literature review of some papers on compensation for compulsory land acquisition from different countries. It was found that there is no definition of adequate compensation in any of the public land acquisition law. Though, nomenclatures like Just, Fair, Equity and Equivalence appears in most statutes, the lack of globally acceptable definition of adequate compensation has resulted in the adoption of different basis for market value by valuers/appraisers for compensation. Some laws, like Nigeria Land Use Act of 1978, stipulate the methodology and identify what improvement qualifies for compensation. The study further revealed that Nigeria authorities always rely on government valuers' estimate of compensation amount. The study recommend for a global standardised definition of adequate compensation and methodology for assessment of compensation similar to international financial reporting standard (IFRS) and international valuation standard (RICS Red Book) for other valuations. Such standard will be expected to be incorporated in the statutes on land purchase and compensation to create a global uniformity and sustainable valuation of compensation for land acquisition.
\end{abstract}

Keywords: Compensation, Compulsory Acquisition, Global, Uniformity, Valuation.

\section{INTRODUCTION}

Compensation for compulsorily land acquisition has continued to attract debates globally in the area of the adequacy of claim payment whether or not it is in the spirit of the definition of compensation. The increasing rapid growth of countries coupled with high demand for land and the pressure on government to provide public amenities to meet the need increasing population has inevitably lead to government exercise of its power of eminent domain. Debates have identified inefficient process of compulsory acquisition with its resultant effect on economic growth (FAO 2008; Bello and Olanrele 2016). Though compulsory acquisition for development purpose is expected to be beneficial to the people, it is usually a disruptive exercise with its attendant displacement of original land owners, occupants and businesses (with loss of patronage and loss of goodwill). It often results in homelessness to some people leaving the affected persons with a wound of grave injustice.

It is understandable that the present era of sustainability in every aspect of human endeavour depends on adequate provision of 
infrastructures in terms of public utilities such as housing, schools, health institutions, transport and power/energy, drainages and other welfare goods from the government. Vital to the provision of the public good is the acquisition of land. Where suitable land are not available to purchase through land market, the government exercise its power of compulsory purchase by compelling the land owners to sell their interest in their properties to government for the actualization of a specific purpose of development of public infrastructure (FAO, 2008). Thus, public land acquisition is an inherent power of government to acquire land rights compulsorily for a beneficial purpose to the entire society. This power is possessed by the governments of every country though under different laws or statutes. Some countries have their land acquisition statutes embedded in the constitution (United States, Rwanda, Ghana, Chile) while others enacted specific Acts on compulsory land purchase (United Kingdom, Australia, Malaysia, Nigeria) and the various declaration for the protection of land rights. Land acquisition operates under the concept of eminent domain, which bestows on the state power to acquire private property even without the owner's consent. This power is vested with the federal and state governments, and can be exercised to acquire any land for any bona fide public purpose with just compensation paid to the landowner (Alias, 2012).

Resettlement is another way of making compensation for acquired land especially with agricultural land. This is considered as alternative to monetary payment of compensation provided for in some statutes. In Ghana and Australia, alternative land can be provided for any land taken, while Canada provides a "Home for Home" resettlement in lieu of monetary compensation. Nigeria Land Use Act provided for resettlement of displaced home owners in a new accommodation but without principle of equivalence and equity. The law stated that claimant will be deemed fully satisfied if the value of resettlement is lower than the value of property acquired but treated excess value of the resettlement over acquired property as loan to be repaid by the resettled owners- a situation of double standard that put the claimants on a receiving end. Denmark uses land consolidation techniques in compensation for farmlands through resettlement as full compensation when value of settlement is lower than the value of land acquired (FAO, 2008). In case of financial compensation, the basis should be the principle of equity and equivalent where the money paid should be able to fully replace the lost and put back the claimants on their immediate position before the acquisition. This rarely occurs in practice. Under the principle of equity and equivalence of compensation is the requirement of provisions that guides and allows assessment of adequate and equivalent amount of compensation.

A cross sectional look on the various public land acquisition and compensation process and practice reveals differences in what could be termed adequate compensation in its true sense as the method of assessment and the list of item/objects that can be compensated for are provided by the enabling Law. This study is conceived to search for global uniformity in the meaning (and method of assessment) of compensation. The following sections examine the process of exercising the power of eminent domain in some countries of the world across the whole continents in a literature search. The methodology of the study follows with analysis and findings and conclusion in the last section.

\section{OVERVIEW OF COMPULSORY LAND ACQUISTION}

Compulsory land purchase is the implementation of the power of government to acquire private interest in land (land rights of individuals) through the exercise of the power of eminent domain for the purpose of public good. However, these cannot be undertaken without the backing of a law or statute. Therefore, public land acquisition by government in any society (Country) is usually legally backed by provisions of an enabling law. Such laws may provide for an acquiring agency that undertakes the acquisition for the government, usually a department of the government; laid down the specific process and procedure and make monetary compensation (or resettlement) to affected owners. Most Acts also defines the meaning of compensation and expected the value is fair to the affected land owners. The law may also specify the method of assessment of compensation sum for the acquired land.

In the United States, the power to compulsorily acquired land is contained in Article $\mathrm{V}$ of the Constitution and there is provision for just compensation (FAO, 2008). The Rwanda's constitution provided that public purchase of land can only be the reason for the provision of public utilities in line with established laws (where details and court interpretation were stated) and a fair 
compensation must be paid before the effective possession of the acquired land, this was stated in Table II, Article 23 (FAO, 2008). The Constitution of Ghana listed the projects and purposes for which there can be compulsory land purchase (Chapter 5, Article 20). The displaced persons can be resettled in an alternative land especially agricultural land. The Chilean Constitution through Chapter III, Article $19 \& 24$, in addition to purposes of acquisition, identifies the owner's right to court action, specifies the method of assessment for compensation purpose and the timing and sequence of taking possession. All land in Hong Kong is practically a leasehold or licence land with the exception of St John Cathedral Church which has a freehold title. Compulsory land acquisition is governed by the Basic Law of Hong Kong Administrative Region of the Peoples Republic of China 1990 (a main Constitution of Hong Kong). It was stated in Article 105 that compensation shall be equal to real value of the property.

Compensation in Australia is regarded as a matter of statutory entitlement and it is based on the principle is of "just term" as provided in section 51 of the Australia constitution which is also enforced in the NSW under the Land Acquisition (just terms compensation) Act of 1991. 'Just Term' is not defined in the constitution but assumed to be 'value to the owner' principle which acknowledged that compensation is more that the market value of the land taken (Chan 2008). This principle does not only retain the concept of market value but also take into account any disturbance to the claimant as a result of the compulsory purchase of their interest in land, bringing the compensation sum to be above the ordinary sale price of the acquired land obtainable from a willing buyer.

Compulsory land acquisitions in other countries are backed with extensive laws in addition to constitution provision. The Acts/laws specify the purpose of land acquisition, agencies to exercise the power of eminent domain, method of valuation for compensation and handling of claims and appeals that may result (mostly in reference to tribunal or court). In the UK (in the $19^{\text {th }}$ Century) early legislations identified situation for compensation in an event of compulsory acquisition but left the amount of compensation for the courts to decide. The UK court view compensation as the value loss to an owner of acquired land with no consideration for deprivation of a betterment which others whose land are not acquired could benefit from, creating a huge disparity of value between the claimants and their unaffected neighbour. The compensation bases shifted in 1917 to market value from the view of the court and through the Land Compensation Act of 1961 in its section 5, compensation for acquired land is ...."the amount which the land if sold in the open market by a willing seller might be expected to realize" - The open market value (Plimmer \& Dubben, 2003).

The notion of adequate compensation is conceived in the Article 13 of Malaysia Federal Constitution of 1957 but the attributes of adequate compensation is yet to be fulfilled by Land Acquisition Act, 1960, which is the stipulated law on compulsory land acquisition and compensation in Malaysia. (Alias \& Daud, 2006; Anuar \& Md Nasir, 2008). The land administration law is the Land Ordinance Code of 1965 operative in all the states of the Peninsular Malaysia (which has been reviewed many times which the latest in 2016). In Nigeria, the Land Use Act (Decree No. 6) of 1978 governs the process of public land acquisition for public purpose, the reasons and procedure are contained in section 28 and section 29 of the same Act provided for compensation with clear mention of items that can be compensated for and the method of assessment of compensation amount (Bello and Olanrele, 2016).

A fair approach to land acquisition arises when the people's right over their land is respected and adequate compensation is paid to displaced people. This is provided in the different laws on compulsory acquisition of land across countries and also in the constitutions of different countries. There are also declarations for the protection of land rights and payment of compensation when land rights are compulsorily acquired. Such declarations include:

- Universal declaration of human rights (Article 17)

- The American convention in human right 91996 Article 21 - Right to property)

- $\quad$ African chapter in human and peoples right, 1986 (Article 14 and 21)

- European convention in human right and fundamental freedoms 1950 "(Article 8)

- Habitat Agenda - Istanbul Declaration in human settlement 1996 (Paragraph $40 \mathrm{~m}, \mathrm{r}, \mathrm{s}$ ) 
- Intentional labour organisations convention concerning indigenous and tribal people in independent countries (No.109) article 14 (1)

\subsection{Divine Overview for Compensation in Land Acquisition}

Compensation is a term that has been adopted in a number of statutes, and used in different context. According to Alias and Daud (2006) it has a meaning for worker's compensation, a different meaning under the law of contract and tort and when used with respect to land right acquisition, it means the sum payable to a disposed land owner for the land taken plus other losses suffered as a result of the compulsory land purchase. Alias (2012) reveals that the law of land acquisition is principally concerned with the rules governing the procedure of compulsory acquisition of land as well as the compensation for the dispossessed landowner. But, other than by acquisition, the government actually has other options to secure land for development, for instance via joint venture or direct purchase through negotiation. In the process of compulsory acquisition is a valuation of the acquired landed property for compensation to the displace land owners/holders. Usually the acquiring authority values the property in accordance with the provision of relevant statute. Where another body or institution does the valuation, the acquiring authority considers the claim and offer what it believes is appropriate and adequate to land owners. This usually results in claim and counterclaims over the adequacy of the compensation value in line with the principle of fair and just compensation.

The Holy Qur'an has stressed the importance of fairness in business: "And, $O$ my people, give full measure and weight justly, and defraud not men of their things, and act not corruptly in the land making mischief. What remains with Allah is better for you, if you are believers" (xi. 85-86). These verses explained that commerce can flourish under conditions of peace and security. The people are, therefore, warned not to disturb the peace of the land so that there is a free and untrammelled trade between different parts of the world. In commercial relations one are expected to be absolutely just and honest, liberally giving other people their due. One are not to be guilty of selfish greed and not to indulge in profiteering; and one are told that the lawful profit which has God's blessings is the one that able to make through perfectly honest dealings with others. The injunctions contained in these Qur'anic verses and found elsewhere in the Holy Book close the door of all dishonest and unjust transactions and justice is a master virtue.

Another example of 'fair value' for a compulsorily acquired land was presented in the Bible "And it came to pass after these things, that Naboth the Jezreelite had a vineyard, which was in Jezreel, hard by the palace of Ahab king of Samaria. And Ahab spoke unto Naboth, saying, Give me thy vineyard, that I may have it for a garden of herbs, because it is near unto my house, and I will give thee for it a better vineyard than it, or if it seem good to thee, I will give thee the worth of it in money - 1King 21:1-2". Fair value is defined in same spirit with the market value as "the amount for which an asset could be exchanged, or a liability settled, between knowledgeable willing parties in an arm's length transaction.

\subsection{Open Market Basis of Value Estimate for Compensation Purpose}

The open market value contains no ambiguity to valuers (valuators or appraisers) as it is properly defined in valuation standards to mean "the estimated amount from which a properly should exchange on the date of valuation between a willing buyer and a willing seller in an arm's-length transaction after proper marketing wherein the parties had each acted knowledgeably, prudently and without compulsion (Blackledge, 2009; Plimmer \& Dubben, 2003; Anuar \& Nor Hana Asyikin, 2010). This means the valuers can still go ahead to value acquired property on the basis of actual transaction in the open market despite the acquisition nature which is compulsory. However, it has become difficult to use market value for a variety of reasons in poor economy due to nature of land right and quality of property. Therefore, alternative approach can be employed. In most cases replacement cost is adopted in many countries and inserted in the land acquisition laws. South Africa uses the replacement cost to value properties/improvement for compensation purpose, but to the replacement cost is added additional fund (a percentage of the cost) to arrive at adequate value of improvements for the purpose of compensation. In India, various approaches are adopted to assess the replacement cost of the acquired land and then the highest value is choose as compensation sum. Nigeria Land Use Act of 1978 specifies 
Depreciated Replacement Cost (DRC) to determine value for compensation (Bello \& Olanrele, 2016; Kakulu, 2008).

In Poland, agricultural land are valued with regard to location, soil quality, timber, agricultural infrastructure and extend of development and any loss of profits and it can be concluded that improvement are valued in various ways depending in their nature. Buildings on the basis of their market value, or replacement costs, perennial crops or trees can be based on their yearly produce value and capitalised for their productive years at the industry's competitive rate of return while timber can be on market value (FAO, 2008). Vaughan and Smith (2014) affirmed that compensation assessment in an event of compulsory land acquisition is to be based on the "principle of equivalence" in other to ensure that disposed owners are fully compensated for the loss suffered. The cost of relocation (of business) and temporary loss are also part of compensation sum under the principle of equivalence in public land acquisition and compensation exercise.

\subsection{Assessment of Value for Compensation}

Assessment of amount of compensation in the event of compulsory land acquisition in the United Kingdom is carried out on the basis of a "no scheme world" considering a situation where the project behind the compulsory acquisition has not come into existence so that no addition of the benefit from the proposed project is considered in the valuation process and such are not compensated for. This means that acquiring authority, will not pay compensation for value created by its own project underlying the acquisition (Plimmer \& Dubben, 2003). It was further opined that claimants are likely not to get the true value of their landed property and will definitely be unable to replace their acquired property. This is because after the scheme, the value increment will not be benefitted by the claimant. This is in consideration of the benefit of enhanced value from the new project to other owners whose property may not be acquired. The creation of the statute is an unequal financial position as benefits of enjoying value appreciation goes to the owners of the retained lands (in form of betterment) while same is denied to others (who sacrifices their interest in land) for the project as the betterment value is not considers as loss suffered. Rowan-Robinson and Hutchison (1995); Anuar \& Md Nasir (2008) reported on dissatisfaction of claimants to the settlement and compensation process and suggested changes to the compensation process in order to reduce hardship on affected land owners during public land acquisition.

In Australia, various level of government (Common wealth, State and Territory), have separate laws that guide compulsory land purchase and compensation. The compensation valuation principle in respect of freehold land is straight forward and consistent but different assessment principle for leasehold land in different states and territories (Chan, 2008). The principle of "value to the owner" is incorporated into the nine (9) compensation laws across the Australia. The matters for compensation under Australia laws as identified by Brown (2004) are described differently in the statutes but include:

- Market value of land

- Special value as may be due to ownership or use of land

- Severance loss

- Disturbance

- Injures affection

- Solation (Payment for disruption, nuisance or inconvenience)

The compensation provision in Hong Kong does not consider injurious affection and solatium, and 'value to the owner' is not applicable. The compensation principles are contained in the Land Resumption Ordinance (LRO) in chapter 12 (Chan, 2008). The compulsory purchase and compensation practice in US provides payment for loss of goodwill, loss of earnings, disturbance as well as cost of relocation, cost of new stationery and professional fees (in respect of business premises). Malaysia law agrees with the open market value basis for compensation but no provision is made for the losses of goodwill and earnings. The compensation for compulsorily acquired land under the Nigeria Land Use Act did not accept the market value approach but a DRC for unexhausted improvements with no compensation for incidental losses.

Generally, compensation valuation should be based on the value of land right, any improvements to the land and other related costs or incidental losses. The principle should make reference to the market value or just compensation. Subsequently, the compensation is expected to cover all loses arising from compulsory land acquisition to make it sustainable must include the following: 
- $\quad$ Land acquired

- $\quad$ Building

- Other crops improvements

- Reduction in value of retained land

- Disturbances

- Severance

- Injures affection

- Fees

The appropriate method to determine compensation is the open market valuation approach.

\subsection{Public Land Acquisitions and Compensation Experience in Nigeria}

The provision for compensation in recognition of the compulsory nature of the public land acquisition with disregard for decrease or increase in value created by the underlying scheme can be interpreted and analysed, where there is reduction in value it is understandable that the reduction is not the making of the claimants. So, open markets value will be favourable and ensure that compensation will place the claimant on a position not less than before acquisition. However, what is the consideration for the others whose land were not acquired but suffers loss in value due to the project of acquisition. The law disregarded any compensation for such people. On the other end, where a value increase is created after acquisitions, the claimant will not be able to purchase a similar property to the one acquired, then the land owners whose land are not acquired will then gain more than the claimants. Although, the betterment tax is meant to reduce irregularity arising from this scenario but to what extent can this be achieved? Betterment tax is a fraction of the increment in value and not the total value gain.

The public purpose/public interest need for compulsory land acquisition are of good and clear intention when such land are required for public uses like school, hospital, road airport, railway, electricity. However, it can be confusing where private land is acquired, subdivided and transferred to private developers/business for private use based on a belief that change in use and ownership of land will give highest and best use of land and benefit the public. In some developing countries (Nigeria inclusive), land are usually assembled through compulsory acquisition to support urban renewal programme to attract commercial development in blighted/slum areas, where there is obvious deterioration of building and infrastructure (FAO, 2008).
In Nigeria, the power of expropriation is abused through unfair procedures or purposes and inequitable compensation with high level of corruption (Bello and Olanrele, 2016). The power to revoke land right is often used to victimise and frustrate political opposition members where the purpose of acquisition is bias and not for public interest. In some cases, acquisition were done and the acquired land are not committed to any use or development for a long period that the original land owners reenter to sell same land to unsuspecting members of the public. Only for the buyer victims to come to the awareness of the acquisition when they are about to commence their private development. In other cases, compensation is grossly inadequate while public officials enrich themselves in a corrupt way. The staff of acquiring authority does the valuation and payment of compensation. The exercise, apart from the inadequacy provided by the law, is bedevilled with corrupt practices where officials feed fat on the compensation sum while the claimant are paid peanuts and cannot recover their losses (Bello \& Olanrele 2016). According to FAO (2008), there can be land restitution opportunity where claims and compensation can be subjected to negotiation or appeal if land that is acquired is more than needed for the purposes of acquisition or when the purposes is no longer relevant. This rarely occurs in Nigeria.

Oladapo and Ige (2014) investigated claimant's satisfaction of compensation in respect of a public land acquisition in Ondo State of Nigeria, their study reported a wide disparity between the amount of compensation and market value of the acquired properties. Bello and Olanrele (2016) found a difference of $46 \%$ in the claimant's expected value and the actual compensation paid in a compulsory purchase in Ogun state of Nigeria in the year 2012. There is evidence of lack of suitable method for compensation assessment and nonstandard in compensation process in Nigeria, as the law is full of ambiguity and lack of clarity (Kakulu et al., 2009). Kakulu (2008) earlier found the provision for compensation in Nigeria to be inadequate Nuhu (2008) noted, in addition to delayed payment, the inadequacy of compensation under the Land Use Act of 1978. Famuyiwa and Omirin (2011) found inadequate compensation to the land owners whose rights were acquired in Victoria Island, Lagos, Nigeria especially with no provision for injurious affection. In an interview with Associate Professor Dr Anuar Alias by the 
Malaysia News Straits Times for its cover story "Acquisition quandary", compensation inadequacy was also noted in China where an old couple refuse to vacate their home inside a half demolished building with a highway built around the un-vacated property. As a result,

\section{METHODOLOGY}

In the sense of global uniformity for compensation valuation in the case of compulsory land acquisition, the study is a qualitative review of provisions for compensation of some selected countries across the continents in comparison with Nigerian experience. A content analysis methodology is adopted for this study. Content analysis is a research technique that is useful in making replicable and valid inferences through interpretation and coding of textual documents. It systematically evaluate texts, the end result that can be converted to quantitative data if need be (see Nachimas and Nachimas, 1976; Kerlinger, 1986; Krippendoff, 1980 and Weber, 1985). The relevant provisions for claims as well as the basis and method of assessment as contained in the enabling statutes the building became solitary in the middle of the highway as the only building standing and the undaunted couple reside in their apartment. This is only possible because there is no law that empower the government to forcibly acquire land (Alias, 2012). of the countries reviewed were extracted and compared. The analysis focused on the meaning of compensation, the heads of claims and the method(s) of assessment as contained in the compulsory purchase laws. The data set for the study include the view of the word compensation, items to be compensated for and methods of assessment as may be contained in the relevant statutes as these are the pointers to valuation process and value adequacy. In an attempt to have global representation, the selected countries cut across five continents of North America, Europe, Asia, Pacific and Africa. South America is unintentionally left out though it shares similarities with the Africa continent in terms of development. Tables 1 and 2 present the summary of the extracted data relating to the heads of claims for compensation, principle and basis of value assessment.

Table 1: Heads of Claim for Compensation for Compulsory Purchase in Selected Countries.

\begin{tabular}{|c|c|c|c|c|c|c|c|c|c|}
\hline \multirow[t]{2}{*}{ Continent } & \multirow[t]{2}{*}{ Country } & \multicolumn{7}{|c|}{ Categories Heads (Items) of Claims } & \multirow[b]{2}{*}{ Crop } \\
\hline & & Land & $\begin{array}{l}\text { Improvement } \\
\text { / } \\
\text { Building }\end{array}$ & Severance & $\begin{array}{l}\text { Injurious } \\
\text { Affection }\end{array}$ & Disturbance & $\begin{array}{l}\text { Solatium } \\
\text { (Disruption, } \\
\text { Nuisance, } \\
\text { Inconvenien } \\
\text { ce) }\end{array}$ & $\begin{array}{l}\text { Special } \\
\text { Value }\end{array}$ & \\
\hline \multirow[t]{2}{*}{ Europe } & $\begin{array}{l}\text { United } \\
\text { Kingdom }\end{array}$ & $\sqrt{ }$ & $\sqrt{ }$ & $\sqrt{ }$ & $\sqrt{ }$ & $\sqrt{ }$ & & & $\sqrt{ }$ \\
\hline & Denmark & $\sqrt{ }$ & $\sqrt{ }$ & $\sqrt{ }$ & $\sqrt{ }$ & $\sqrt{ }$ & & & $\sqrt{ }$ \\
\hline $\begin{array}{l}\text { North } \\
\text { America }\end{array}$ & $\begin{array}{l}\text { United } \\
\text { States }\end{array}$ & $\sqrt{ }$ & $\sqrt{ }$ & $\sqrt{ }$ & $\sqrt{ }$ & $\sqrt{ }$ & & & $\sqrt{ }$ \\
\hline \multirow[t]{2}{*}{ Pacific } & Australia & $\sqrt{ }$ & $\sqrt{ }$ & $\sqrt{ }$ & $\sqrt{ }$ & $\sqrt{ }$ & $\sqrt{ }$ & & $\sqrt{ }$ \\
\hline & $\begin{array}{l}\text { New } \\
\text { Zealand }\end{array}$ & $\sqrt{ }$ & $\sqrt{ }$ & $\sqrt{ }$ & $\sqrt{ }$ & $\sqrt{ }$ & & & $\sqrt{ }$ \\
\hline \multirow[t]{2}{*}{ Asia } & $\begin{array}{l}\text { Hong } \\
\text { Kong }\end{array}$ & $\sqrt{ }$ & $\sqrt{ }$ & $\sqrt{ }$ & & $\sqrt{ }$ & & & $\sqrt{ }$ \\
\hline & Malaysia & $\sqrt{ }$ & $\sqrt{ }$ & $\sqrt{ }$ & & $\sqrt{ }$ & & & $\sqrt{ }$ \\
\hline \multirow[t]{3}{*}{ Africa } & $\begin{array}{l}\text { South } \\
\text { Africa }\end{array}$ & $\sqrt{ }$ & $\sqrt{ }$ & & & & & $\sqrt{ }$ & $\sqrt{ }$ \\
\hline & Nigeria & & $\sqrt{ }$ & & & & & & $\sqrt{ }$ \\
\hline & Rwanda & $\sqrt{ }$ & $\sqrt{ }$ & $\sqrt{ }$ & $\sqrt{ }$ & $\sqrt{ }$ & & & $\sqrt{ }$ \\
\hline
\end{tabular}

Table 2: Principle and Basis of Compensation for Compulsory Purchase in Selected Countries.

\begin{tabular}{|l|l|l|l|l|l|l|l|l|}
\hline \multirow{3}{*}{ Continent } & \multirow{3}{*}{ Country } & \multicolumn{3}{|c|}{ Compensation Principle } & \multicolumn{3}{c|}{ Basis of Valuation } \\
\cline { 3 - 8 } & $\begin{array}{l}\text { Just/Value to } \\
\text { the Owner }\end{array}$ & $\begin{array}{l}\text { Equity and } \\
\text { Equivalence }\end{array}$ & $\begin{array}{l}\text { Fair } \\
\text { Value }\end{array}$ & Cost & $\begin{array}{l}\text { Market } \\
\text { Value }\end{array}$ & $\begin{array}{l}\text { Replacement } \\
\text { Cost }\end{array}$ & $\begin{array}{l}\text { Depreciated } \\
\text { Replacement } \\
\text { Cost }\end{array}$ \\
\hline
\end{tabular}




\begin{tabular}{|c|c|c|c|c|c|c|c|}
\hline \multirow{2}{*}{ Europe } & $\begin{array}{l}\text { United } \\
\text { Kingdom }\end{array}$ & $\sqrt{ }$ & & & $\sqrt{ }$ & & \\
\hline & Denmark & & $\sqrt{ }$ & & $\sqrt{ }$ & & \\
\hline $\begin{array}{l}\text { North } \\
\text { America }\end{array}$ & $\begin{array}{l}\text { United } \\
\text { States }\end{array}$ & $\sqrt{ }$ & & & $\sqrt{ }$ & & \\
\hline \multirow[b]{2}{*}{ Pacific } & Australia & $\sqrt{ }$ & & & $\sqrt{ }$ & & \\
\hline & $\begin{array}{l}\text { New } \\
\text { Zealand }\end{array}$ & $\sqrt{ }$ & & & $\sqrt{ }$ & & \\
\hline \multirow{2}{*}{ Asia } & Hong Kong & $\sqrt{ }$ & & & $\sqrt{ }$ & & \\
\hline & Malaysia & $\sqrt{ }$ & & & $\sqrt{ }$ & & \\
\hline \multirow{3}{*}{ Africa } & $\begin{array}{l}\text { South } \\
\text { Africa }\end{array}$ & & & $\sqrt{ }$ & & $\sqrt{ }$ & \\
\hline & Nigeria & & & $\sqrt{ }$ & & & $\sqrt{ }$ \\
\hline & Rwanda & & & $\sqrt{ }$ & $\sqrt{ }$ & & \\
\hline
\end{tabular}

\section{RESULT AND DISCUSSION}

The study found compensation as a term that is used in compulsory land acquisition to have same meaning in all the land acquisition statutes across the countries that were examined in this study. Compensation therefore means 'the sum payable to a disposed land owner (claimant) for the compulsorily acquired land, to place the claimant in the same position he was immediately before his/her right in land is taken, not better, not worse'. Such amount is expected to include all other incidental losses that may be suffered by the displaced land owner. However, the principle and basis of assessment are the area of differences in compensation process.

Table 1 presents the various items upon which a dispossessed land owner can make a claim for payment of adequate compensation in the different countries of study. These heads of claims are provided for by the relevant statute of each nation state. Except for a special value which only South Africa provided for in addition to replacement cost of acquired property, Australia portend the most adequate compensation with the inclusion of 'solatium'which is payment for disruptions, nuisance and inconveniences caused land owners as a result of the compulsory purchase of land. Hong Kong and Malaysia do not recognise injurious affection as an item of compensation claim. Most developed western countries of Denmark, New Zealand, United Kingdom and United States recognised all listed items of compensation claim with the exclusion of solatium. Rwanda in the Africa continent also have similar provision like most of the developed western countries, land is also compensated for. Nigeria only provided for unexhausted improvement on land and perennial crops, this is the least and most inadequate compensation provision among the countries examined in this study. There is no provision for compensation for land in the Nigeria Land Use Act because all land are held in trust by governor of each state as provided in the law. The South Africa provision of special value in addition to the replacement cost of the acquired landed property can be assumed to suffice for severance, injurious affection and disturbance but its adequacy is in doubt as a percentage of replacement cost that is considered as special value may not be enough to cover disturbances and injuries suffered by land owners as a result of forceful purchase in the real sense. The Scotland provision for home or farm loss (as the case may be) in addition to other head of claims is in term of true compensation (Anuar et. al., 2011). Alias and Daud (2006) suggested an inclusion of solatium or premium through review of compensation claims in Malaysia in support of the submission of Dundas and Evans (2001) that if market value basis of valuation is considered satisfactory towards achieving adequate compensation, an additional payment should be made to all disposed land owners.

The principle behind compensation in the advent of public land acquisition is related to the valuation basis and methodology for assessment of compensation amount. The three Africa countries in this study operates 'Fair' principle. Other countries adopted 'Just Value to the Owner' principle with the exception of Denmark that adopted 'Equity and Equivalence' principle (see Table 2). The fair principle of African nations reveal the level of development in the continent as the word 'fair' can become subjective in usage both in respect 
of each country and in relation to each claimant. Whatever is considered fair is then paid as compensation. Nigeria system allows for the use of public land acquisition as an instrument of political war within the political class.

The countries studied except the two Africa giants (Nigeria and South Africa) adopted market value basis for valuation for compensation purpose. This suggests that the open market value of the acquired properties is considered adequate compensation. This will however include a financial assessment of all losses in addition to the market value of the acquired landed property. South Africa adopted replacement cost basis for the assessment of the fair value of acquired property and as such cost method of valuation become appropriate. Nigeria goes further to depreciate the replacement cost of unexhausted improvement on land, thus the law prescribes depreciated replacement cost (DRC) for fair value assessment. Rwanda, though on the same fair compensation principle with Nigeria and South Africa, agreed with developed countries in the market value basis (Table 2). For the countries that consider market value basis for the value assessment, the valuer/appraiser is left to the choice of appropriate valuation method to arrive at market value in full consideration of the type and usage of each subject property of valuation (residential, office/retail, hotel, hospital, logistics etc). Oladapo and Ige (2014) in their study called for valuation methods that will reflect the meaning of compensation because their study identified lack of uniform standard method for compensation value assessment. Bailey and Clough (2009) earlier reported a similar finding of lack of standard method to compensation assessment for farmers in New Zealand when their lands were acquired for a power transmission lines prior to 1988. This study corroborates the earlier findings of inappropriate method resulting in inadequate compensation in not only Africa developing nations but also in Malaysia, China and Hong Kong. The study therefore present that adequate compensation is a function of heads of claims, basis and methods of value assessment. The present study also aligned with the majority in the use of open market approach to value for compensation. Only two of the countries considered in the study adopted other method.

\section{CONCLUSION}

Compensation is not expressly defined in most land acquisition laws; neither does its basis, but left in the hands of operators to assume what it means. This has resulted in the admission of the court definition of compensation with the global understanding that, the displaced property owners are put in same position they were immediately before the acquisition of their right in land. Thus, the adoption of different principles to portray adequate compensation, such as 'Just Compensation'; 'Fair Compensation'; 'Value to the Owner'; or 'Equity and Equivalence' with the basis being the market value. However, Method of valuation is mentioned in the land acquisition laws of some countries and the items to be compensated for are listed in the statutes. The study found that the concept of compensation for acquired land rights is same as understandable across the globe, but the actualisation of adequate compensation with global uniformity seems unachievable. This is because the principle of assessment and method of valuation varies. Under the various principles of Just, Fair, Adequate, Equity, Equivalence or Value to the Owner; it is assumed that the compensation will take into account all incidental losses, and cost to the claimants in other to be placed in same situation before the acquisition. Meanwhile, when most statutes recognised market value basis as the adequate compensation some countries opted for replacement cost basis. However, market value in compensation retains the definition by the International Valuation Standard Committee (IVSC) as contained in the Royal Institute of Chartered Surveyors (RICS)'s Red Book which has been adopted globally. This study agreed with the previous studies that found gross inadequacy in Nigeria land acquisition and compensation practice. It also noted the non-inclusion of injurious affection in the Hong Kong and Malaysia compensation statutes. The special value compensation in South Africa cannot be considered adequate for all losses. In view of the variation in provision for adequate compensation in different countries, this paper suggests an establishment of global uniformity in terms of head of claims covering all losses, and method of assessment which can be recommended for inclusion in every country's law of compulsory land acquisition in order to make it sustainable. Perhaps, an introduction of 'compensation standard code' which will be guided by international standard of valuation for compensation will ensure its sustainability. Therefore, this study concludes that there is a need for global uniformity in valuation basis and methodology for global standard, which should be adopted in compulsory land acquisition laws and implementation and opens 
campaign for such. The paper recognised the non-inclusion of South America and Middle East countries as limitation, as well as the difficulty in implementing the recommendation globally, it therefore suggest a more international debate and commitment towards adequate compensation through value assessment in compulsory land purchase process. As the first attempt on global uniformity in compensation valuation, it is expected that more research on the feasibility of this new advocacy.

\section{REFERENCES}

Alias, A., \& Daud, M. N. (2006). Payment of Adequate Compensation for Land Acquisition in Malaysia. Pacific Rim Property Research Journal, 12(3), 326-349. Alias, A., (2012), Cover Story: Acquisition Quandary - RED - New Straits Times http://www2.nst.com.my/red/cover-storyacquisition-quandary1.178868\#ixzz3JWvIxnRk

Anuar, A, Md Nasir, D., (2008), Compensation for Orang Asli Native Land in Malaysia: The Perceptions and Challenges in its Quantification, Journal of Design and Built Environment (JDBE), Vol.4, No.1, 2008

Anuar A., Noor Rosly H., Peng Yanning, (2011), Land Acquisition Problems in China: Adopting Land Acquisition Act 1960 of Malaysia as a Benchmark, Journal of Design and Built Environment (JDBE), Vol.8, No.1, 2011

Anuar A., Nor Hana Asykin N.H., (2010), Comparison Method - Preference of Adjustment Techniques Among Valuers, Journal of Design and Built Environment, Vol.7, December 2010, pp. 33-42.

Bailey, P. and Clough, P. (2009). Compensation for transmission infrastructure: A Report Presented to the Federal Famers, New Zealand. NZIER

Bello, N. A., \& Olanrele, O. O. (2016). Value gap in Nigerian property compensation practice: measurement and economic effects. Pacific Rim Property Research Journal. doi: 10.1080/14445921.2016.1203235

Blackledge, M. (2009). Introducing Property Valuation. Oxon, UK: Routledge Taylor \& Francis.

Brown, D. (2004). Land Acquisition. Sydney: Butterworths.

Chan, N. (2008, 20-23 January). How Australia deals with land acquisition compensation for land subject to a leasehold title. Paper presented at the 14th Pacific Rim Real Estste Society Conference, Kuala Lumpur, Malaysia.
Dundas, I. H. M., \& Evans, W. M. (2001). Review of Compulsory Purchase and Compensation: Scottish Executive Central Research Unit.

FAO. (2008) Compulsory Acquisition and Compensation. FAO Land Tenure Studies 10. Rome: Food and Agricultural Organisation.

Federal Republic of Nigeria (1978) Land Use Decree (now Act) of 1978. Federal Government Press, Lagos

IVSC (2003) International Valuation Standards International Valuation Standards

Committee.

Kakulu, I. I., Bryne, P. \& Viitanen, K. (2009) "Phenomenological Research in Compulsory Land Acquisition and Compensation: Surveyors Key Role in Accelerated Development" being a paper presented at the FIG Working Week 2009 Eilat, Israel, pp. 3-8 May 2009.

Kakulu, I. I. (2008). The Assessment of Compensation in Compulsory acquisition of oil-and-gas bearing land in the Niger Delta. Land Reform, 1, 57-65.

Kerlinger, F. H. (1986). Foundations of Behavioural research $\left(3^{\text {rd }}\right.$ Ed). New York. Holt Rinehart and Winston.

Krippendorff, K. (1980). Content analysis: An introduction to its methodology. London. Sage.

Nachmias, D. \& Nachmias, C. (1976). Content Analysis: In Research Methods in the Social Sciences (pp 132- 139). United Kingdom. Edward Arnold.

New Straits Times (2015). COVER STORY: Acquisition quandary - RED - New Straits Times http://www2.nst.com.my/red/coverstory-acquisition-quandary1.178868\#ixzz3JWvIxnRk

Nuhu, M. B. (2008). Compulsory Purchase and Payment of Compensation in Nigeria: A Case Study of Federal Capital Territory (FCT) Abuja. Nordic Journal of Surveying and Real Estate Research, 3(Special Series), 102-126.

Oladapo, R. A., \& Ige, V. (2014). Assessment of Claimants' Satisfaction to Variation in Compensation Paid for Compulsory Land Acquisition in Ondo State, Nigeria. Paper presented at the FIG Congress 2014 Kuala Lumpur, Malaysia.

Plimmer, F., \& Dubben, N. (2003, 2-5 December). The land of Make Believe: An Overview of the Assessment of Compensation for Land Taken in Compulsory Acquisition in the nited Kingdom. Paper presented at the 2nd FIG Regional Conference, Marrakech, Morocco. 
Rowan-Robinson, J. \& Hutchison, N. (1995). Compensation for the compulsory acquisition: Satisfaction or sacrifice Journal of Property Valuation and Investment, 13, 44-65.

Scottish Government (2011). Compulsory purchase and compensation: A guide for owners, tenants and occupants.
Vaughan, D., \& Smith, L. C. (2014). An Introduction to compulsory purchase valuation principles spanning 150 years. Journal of Building Survey, Appraisal and Valuation, 3(2), 184-189. Weber, R. P. (1985). Basic Content Analysis. New Delhi. Sage 